\title{
Geographical Assessment of Sacred Groves in Bolpur Sub-division, India Tapas Pal
}

\author{
http://dx.doi.org/10.4314/ejesm.v4i2.6
}

\begin{abstract}
Human culture evolved around sporadic elements of nature. Our ancestors developed a special world view of nature around them. While receiving all the material benefits from nature, they in turn expressed their love \& respect by worshiping elements in nature. One consequence of such nature worship is that different elements of bio-diversity are conserved and best exemplified in the initiation of 'sacred groves'. Sacred groves are patches of natural vegetation dedicated by local communities to worship of ancestral spirits and deities. These groves may consist of a multi-species forestry, a clump of trees belonging to one species or even a single old tree depending on the history of the vegetation and local culture. Local communities because of their religious customary taboos and sanction with cultural and ecological implication protect these groves. These sacred groves have sporadic physical and non-physical dimensions in this study area. The regional peoples can easily conserve their fruitful environment through the preserve species of trees and also curtail the pollution impact from our society with the access of this indigenous model station.
\end{abstract}

Key words: Nature worship, Sacred Grove, indigenous model.

\section{Introduction}

Sacred and human faith is mutually co-related. The degree of sanctity of the Sacred Groves varies from groves to groves. In some cases peoples do not touch even the dry foliage and fallen fruits. They believe that any kinds of disturbance will crucially affect the local deities causing diseases, natural calamities or failure of crops .For example, from this study area Bishaharitalas', 'Brahmacharitala' Sacred Groves of Illambazar block is completely prohibited by any people to enter at this places with shoes, or without eating in whole day or bath or fresh dresses.

Even local peoples enter into these sacred zones without eating. In other groves, dead woods, dried leaves may be picked up but the fresh leaves and its green or brown branches are never cut, for instance,' kankalitala' Sacred Groves of Bolpur. In some Sacred Groves it is completely prohibited to collect drier or fallen or leaf tree and cutting or any hampering for example, 'Bagratala' Sacred Groves of Illambazar. So, these 'mini biodiversity' induced practices have significant religious connotation for the protecting community. Hunting, loggings are usually strictly prohibited within these patches. In some groves other usages likes honey collection, deadwood collection are done on sustainable basis.
Such groves are associated with the concept of 'presiding deity' while most of these sacred deities associated with local Hindu gods, and another related Muslim or aborigines like Santals Kora etc. in the study area.

Sacred Groves act as a capling between human faith and supernatural power. Traditional Sacred Groves are places where village deity resides who is represented by an elementary symbol (taboo) like stones, pictures, photos, natural symbol like lotus, elephant eye, snake head, natural hole within a tree, naturally emergence of stone from sacred surface etc. Cultural Sacred Groves related human culture in respect of their faith upon nature or God or respect to their ancestors. In this case study area Sacred Groves are found in another two angle i.e. singletree based sacred boundary and multi species related sacred zones. Due to successive degradation nature of modern people sacred groves are also adversely affected by them and for this reasons another two angle of sacred groves has been generated from the study area i. e. totally free from human interference and partly affected by human interference.

Department of Geography, Visva-Bharati, Santiniketan, India.

Email: tapas_raigang@rediffmail.com 


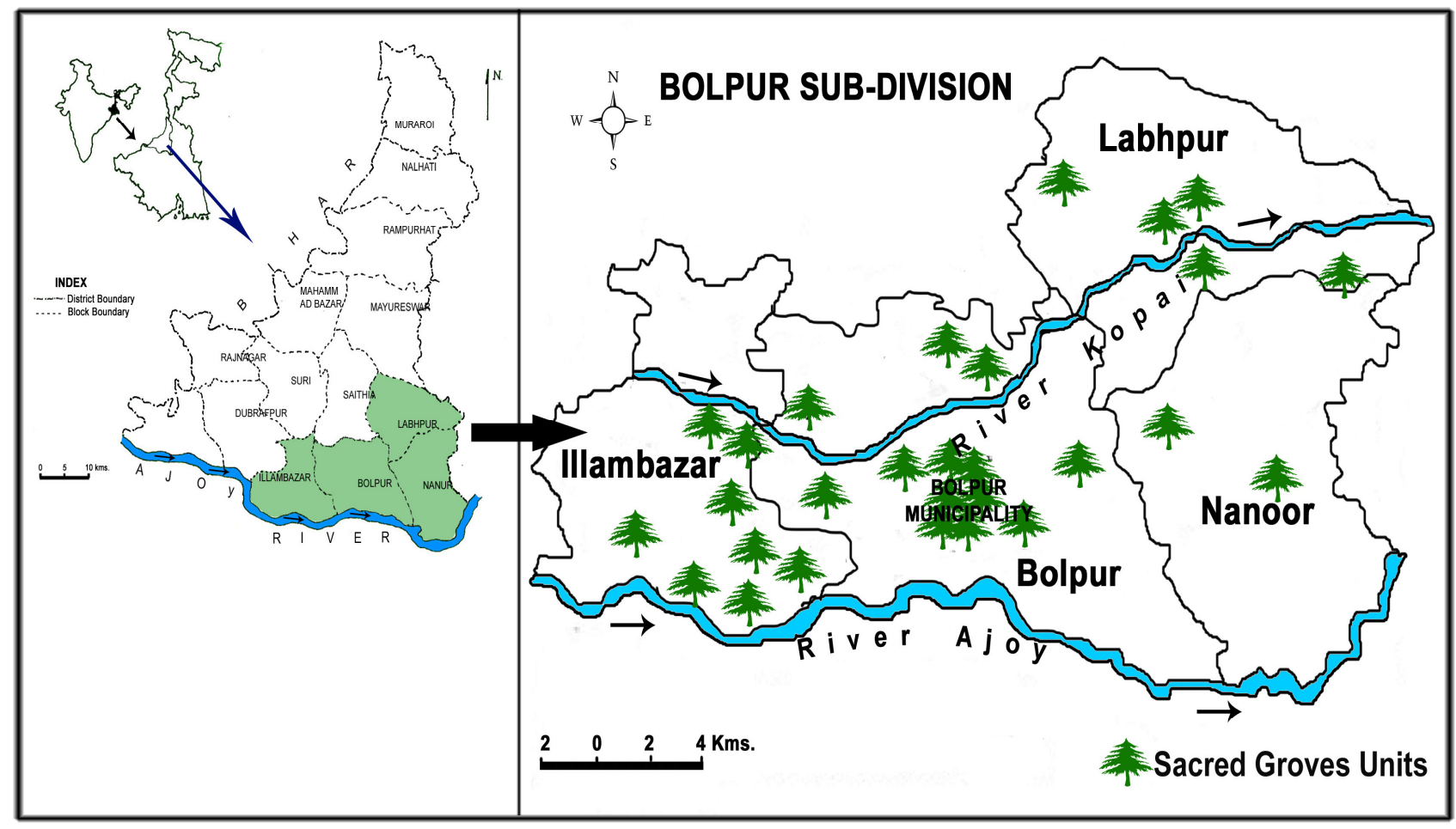

\section{Study Area}

Bolpur in Birbhum district is located in southeastern part of the district with a total area of 1173.5 sq. kilometers. It extended from $23^{\circ} 32^{\prime} 30^{\prime}$ 'to $23^{\circ} 53^{\prime} 00^{\prime \prime}$ north latitude and $87^{\circ} 23^{\prime} 30^{\prime \prime}$ 'to $87^{\circ} 57^{\prime} 30^{\prime \prime}$ east longitudes. This sub-division comprises four police stations viz. Bolpur (333.6 sq.km. area), Illambazar (259.5sq. Km area), Labhpur (area of 333.6 sq.kilometers), Nanoor (309.2 sq.km area).

\section{Methodology}

A total 41 different Sacred Groves in Bolpur subdivision area were randomly surveyed. To analyze the primary data author used total 45 questionnaires like; the name \& location of sacred grove, age of Sacred Groves, festivals related Sacred Groves, improved infrastructures around these sacred groves, how local peoples use their Sacred Groves, their perception about their Sacred Groves, do local people uses their sacred trees as ayurvedic medicine etc..

The respondents were mainly elderly local peoples of that area with age ranging from 45-80 and the samples were randomized. Scientific names of the plants were obtained with the aid of standard herbarium samples compiled by biological sciences students.. To locate the place of sacred groves author used mapping process and to elaborate the real evaluation, author collect sporadic photos from field on the basis of randomly.

\section{Results and Discussion}

\section{Physical (ecological)}

Sacred groves act as a micro sponger in local level environment through the controlling of rainfall, humidity, temperature, ground water table recharge, oxygen/carbon dioxide regulation, soil fertility, etc. It also checked the initiation of desertification, local and regional soil erosion, pollination and germination processes. It is also the important regulator of local weather condition and soil erosion and filling of local riverbeds as well as flood. Through the Sacred Grove faith practices some ponds are conserved or nearly conserved in Bolpur sub-division area. Sacred ponds are positioned at the entrance of some Sacred Groves and a typical example is 'Fullaratala' - 
Sacred Grove of Labhpur. Some ponds are situated at right side of sacred grove, for example is 'Bishaharitala', of Chella village, Illambazar. Some ponds are located at back side of sacred place and thereby making them relatively free from human interference example 'Kankalitala' temple based sacred grove, Bolpur and all these sacred ponds are Hindu religion based. There are some Muslim religious based sacred ponds related with Sacred Grove places in this case study area, for instance, pond associated along 'Maichampadanga' of Illambazar. But some ponds are positioned close to it which nearly conserved for sacred groves units i.e. these ponds are used for sacred worship but some time devotees may take their bath in them as well as occasional incidence of animal sacrifice during worship for example, 'Kalishah' of Bolpur,'Fullarahtala,' of labhpur,' 'Dakshinakalitala'- Nanoor. The floral composition of the sampled sacred groves are shown in figure 1. The protection of patches species as sacred trees belong to the religion based conservation ethos of ancient people of these case study area.

In context of biological conservation, pond ecosystem can also be preserved as these ponds serve as breeding sites for some animals and recreational facilities. Groves of Bolpur sub-division area also create 'conservational foliage' to protect the rare trees which are vulnerable to exploitation. For instance, wild belly and sugar tree (local name) in Dhallayh village of Illamrazar, Vitis quadrangularis (scientific name of harjora ephiphyte) in Kankalitala, Bolpur \& Hatichakhkhu (local name) in Illambazar_Generally sacred trees are so many hundred years old in Bolpur sub-division area. So, after naturally falling of these trees it become a scientific resource to determine the paleo -climatic nature of this study area

\section{Socio-cultural Values}

Sacred grove and sacred old cultural worship processes are related with human behaviors as expressed by appreciation of nature though conservation of groves and trees. Collection of dry leaves, stems, fruits, honey and animal grazing are some of the economic benefits associated with these units at the local level. In some sacred worship related fair and festival vertical economy is spurt out and local economy is energized. On such worship days large numbers of people come to the sacred ground $\mathrm{s}$ and for the whole day they socialize and exchange pleasantries. So, sacred groves promoted friendship and positive attitudes among the peoples.

Sacred groves provide inspiration and highlight the essentials of harmony with nature, social unity, and human love of nature in the vista of trees conservation. In this age of development, people should try to adopt the conservation of vegetation through grove units on the basis of their sacred faith. Therefore the poor beggars momentarily forget their problems and hunger and for one day people change their daily behavior. Some sacred groves are purely natural which become as a regional heritage site to see and visually enjoy as a unit of natural vegetation delineated area an urbanized area. Some have rare visible sacred symbols for example a natural lotus is found on a sacred Neem tree at 'Gutulikalitala', Monoharpur, Nanoor ,Hatichokkhu tree of Maichampabibidanga of Illambazar. Another rare visible sign that is, a rock (Chandi - a Hindu god) naturally is being emerging at 'Sivchanditala' of Illambazar. More over old human faith and culture related sacred grove must be structured as a world mini-heritage site with huge tourism potential. This accumulation of sacred groves is the miniature form of local and finally world forestry. Because these places are exposed to minimal human interference there is higher propensity for regeneration of the endemic species in such groves. Sacred ground is functionally more improved by modern water supply system, new tube well constructed, cementing sacred fielded, properly drained system, winsome visible lighting water dance system, specific human seating places, concretization of sacred ponds etc. for example, labhpur of 'Fulloratala', 'Bisharatala' of Illabazar have been modernized by above infrastructure characteristics. Formation of new concrete temple is also an infrastructure improvement symbol in 'Shivchandi' sacred grove unit in Illambazar. During festival period at least peoples reached to these near or near site and also outer peoples reach to at these area and they known what is being there. Many medicinal trees are being conserved through these sacred groves. 


\section{Conclusion}

Threats has malevolent noxious site to Sacred Groves .It differs from one grove to another. But some common threats identified are as summarized below. Disappearance of the traditional belief system for example, a Sacred Grove has now a day disappeared from Dallaha village of Illambazar. Most of the units in Bolpur Municipality area were moved to temple from. Due to impact of modernization for example 'Hatichakkhu' (local name) a sacred tree in Illambazar block has been adversely affected by their odd unusual hand writing. The integrity of many groves with regional or pan Indian character has suffered due to the influx of large number of pilgrim and tourist. Pilgrim's un eco-friendly polluted behavior changes the natural identity of these sacred zones. In different parts of this Bolpur sub division area, local folk deities have been, continuous replaced with Hindu gods and goddesses and have resulted in erection of a temple in the Sacred Groves. Sacred Groves have been encroachment by local communities, governmental activities, migrated persons and tourist persons. Daily clearing of sacred ground by local people by brome to collect dead leaf, fruits, stems are not deposited and accumulated on land and due to lack of accumulation plants organs, regermination, polenization of trees or plants are being stopped. Moreover due to cycling of beating by brome huge number of micro organisms, tiny grassroots animals insects, animals etc. are become follow the 'door of Yama' and ground level bio-diversity become debacle.

\section{Recommendations}

1. Cutting, cyclic running or clearing the under growth vegetation, climber, herbs, shrubs, within the sacred groves should be discouraged.

2. Ancestral cultural viewpoint and processes should be preserved as they form the origin and basis for the sacred groves and over time these grove units could become mini natural heritage sites.

3. Bathing in sacred pond should also be discouraged to avoid chemical pollution.

4. Tourists should follow eco-friendly behavior while at the sacred groves places

5. Government and local legislative assembly should publicize and advertise sacred groves idea to attract outside tourists.

\section{Acknowledgement}

The author would like to express his sincere appreciation to Prof Malay Mukhopadhyay, of Dept. of Geography, Visva Bharati, India, for his guide and initial contribution in this field of research.

\section{References}

Basu, R. (2000), Studies on Sacred Groves and Taboos in Purulia District of West Bengal,Indian Forester,pp 1309-1317.

Bickmann, W, (1984), Traditional medicine and healthcare in Africa,Dev Corp, 9-11.

Bijukumar, A. (1998), 'Sacred groves the virgin forests',J. Science Reporter pp17-18 .

Burman, R.J.J. (1992), The institution of Sacred groves, J. Indian Anthropol.Soc.27:219-238.

Gadgil, M. and Vartak, V.D. (1973), Dev Rahati: an ethnobotanical study of the forests preserved on grounds of religious beliefs Abstract, Proc. Indian Science Cong.60:341.

Gadgil, M. and Vartak, V.D. (1976), Sacred Groves of Western Ghats of India. Economic Botany, 30:152-160.

Jain, S.K. (1997), Medicinal plant \&Rao RR, A Handbook of Field and Herbarium Methods, Today and Tomorrow's Printers and Publishers, New Delhi.

Malhotra, K.C., Chatarjee, Y. and Gokhale, Y. (2007), 'Sacred Grove in India' Aryan books International, New Delhi pp102-122. 
NATURE \& EXTENT OF HUMAN ENCROACHMENT

Totally free from human. interference
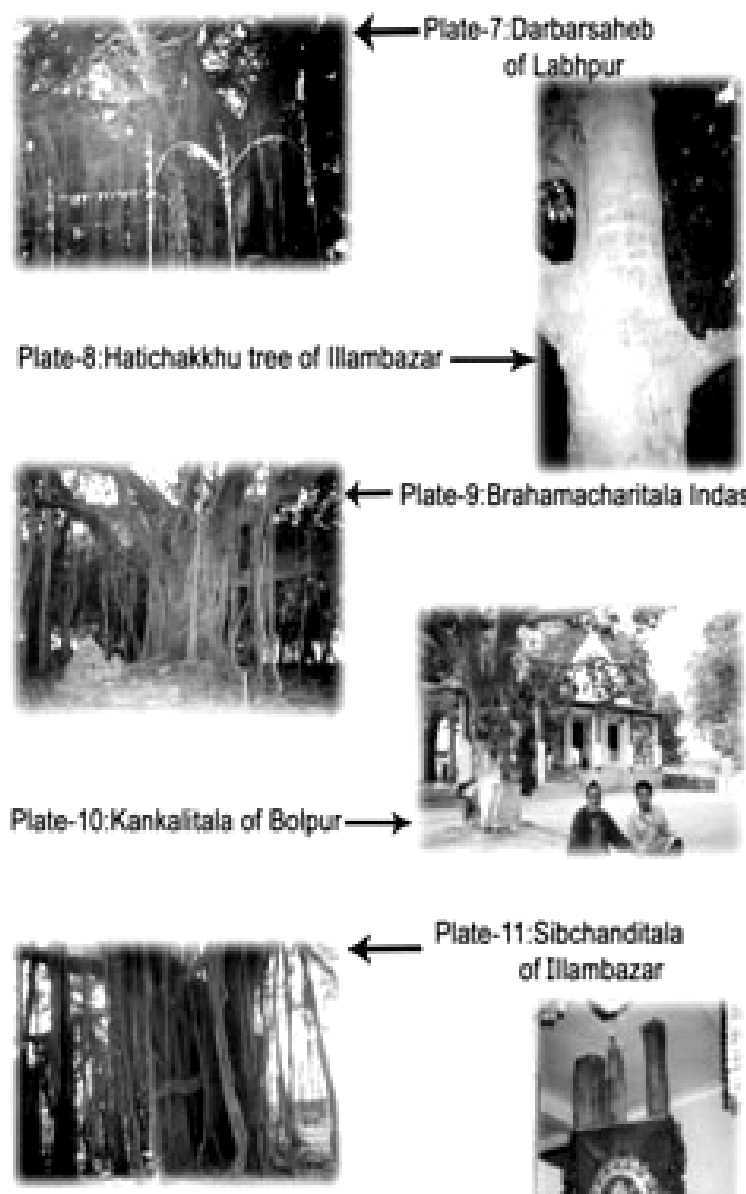

Plate-12:Dangalitala of Bolpur

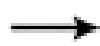

Inference: Away from the urban centre human 11:Sibchanditala of Illambazar

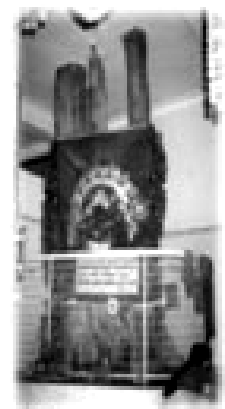
inteference is becoming less

\section{SINGLE \& MULTISPECIES SACRED GROVES}
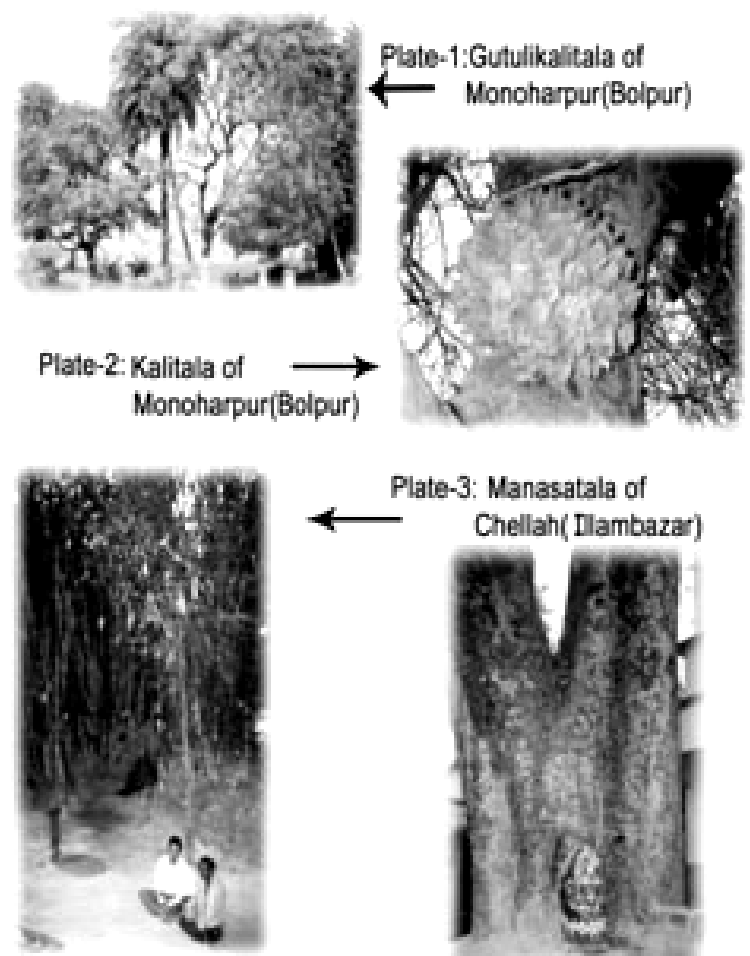

Plate-3: Manasatala of Chellah( Dlambazar)

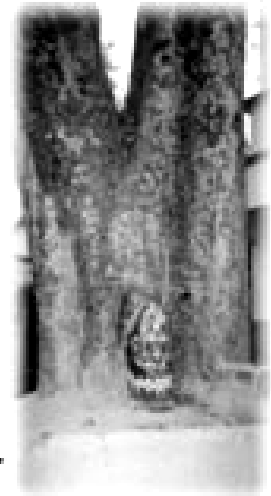

Plate-4: Shivtala of Jambuni(Bolpur)

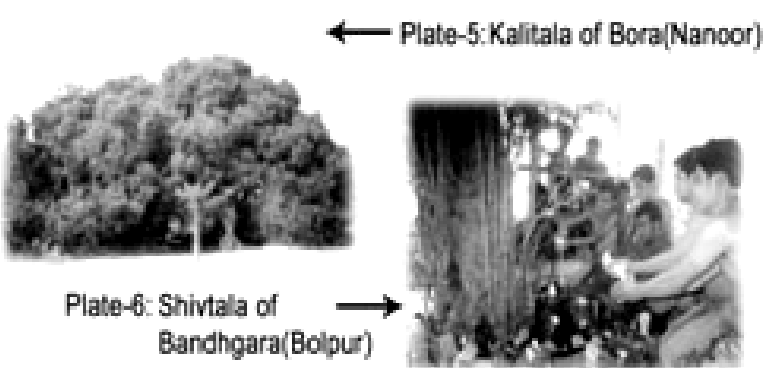

Inference: Away from the urban centres number of species wihtin sacred grove units is increasing 
Table 1: Sporadic Diversity Of Sacred Trees In The Following Blocks In 2009-10

\begin{tabular}{|c|c|c|c|c|}
\hline Blocks & $\begin{array}{l}\text { Name of the } \\
\text { villages }\end{array}$ & Name of Sacred Groves & Age & $\begin{array}{l}\text { Scientific Name/ number of sacred } \\
\text { trees }\end{array}$ \\
\hline \multirow{11}{*}{$\begin{array}{l}\mathrm{B} \\
\mathrm{O} \\
\mathrm{L} \\
\mathrm{P} \\
\mathrm{U} \\
\mathrm{R}\end{array}$} & $\begin{array}{l}\text { Bangalpara, } \\
\text { sian }\end{array}$ & 'Shivtala' & 25 & Ficus benghalensis(1) \\
\hline & Trisolapatti & 'Shivtala' & 55 & Ficus benghalensis(1) \\
\hline & Kankalitala & 'Kankalitala' & 200 & $\begin{array}{l}\text { Terminalia arjuna }(89), \\
\text { Ficus benghalensis }(2), \\
\text { Odina woodier }(1), \\
\text { Syzygium cumini( } 1), \\
\text { Ficus infectoria }(5)\end{array}$ \\
\hline & Kankalitala & $\begin{array}{l}\text { 'Kankalitalacremation } \\
\text { ground' }\end{array}$ & 400 & $\begin{array}{l}\text { Ficus benghalensis(2), } \\
\text { Shorea robusta }(8), \\
\text { Vitis quadrangularis }(1)\end{array}$ \\
\hline & $\begin{array}{l}\text { Prof. } \\
\text { colony }\end{array}$ & 'Shivtala' & 25 & Ficus benghalensis(1) \\
\hline & $\begin{array}{l}\text { Near bolpur } \\
\text { high school }\end{array}$ & 'Hanumantala' & 52 & Ficus benghalensis(1) \\
\hline & Nichupatti & 'Dangalikalitala & 350 & Dead Ficus (1),Benghalensis(1) \\
\hline & Sureteswar & 'Shivtalashivdur & 450 & Borassus habellifer(1) \\
\hline & Sriniketan & 'Kalishahmandir' & 400 & $\begin{array}{l}\text { Tamarindus indica(1) } \\
\text { Syzygium cumini(1) }\end{array}$ \\
\hline & Santiniketan & 'Amrakunja \&chatimtala' & 100 & Shorea robusta $(25)$ \\
\hline & Jambuniroad & Kali tala & 50 & Aegle marmelos(1) \\
\hline \multirow{4}{*}{$\begin{array}{l}\mathrm{N} \\
\mathrm{A} \\
\mathrm{N} \\
\mathrm{O} \\
\mathrm{O} \\
\mathrm{R}\end{array}$} & Chandipur & $\begin{array}{l}\text { 'Sasanmartala } \\
\text { (burialplace }\end{array}$ & 20 & $\begin{array}{l}\text { Phoenix sylvestris(8), } \\
\text { Zizyphuba jujube(1), } \\
\text { Acacia nilotica(1), } \\
\text { Streblus asper(1), }\end{array}$ \\
\hline & Monoharpur & 'Gutulikalitala' & 350 & Azadirachta indica(2) \\
\hline & Monoharpur & 'Kalitala' & 250 & $\begin{array}{l}\text { Phoenix sylvestris(1), } \\
\text { Streblus asper(4) }\end{array}$ \\
\hline & Bora & 'Dakshinakalitala' & 400 & $\begin{array}{l}\text { Tamarindus indica }(2), \\
\text { Annona squamosa }(1), \\
\text { Syzygium cumini(1) }\end{array}$ \\
\hline \multirow{5}{*}{$\begin{array}{l}\mathrm{L} \\
\mathrm{A} \\
\mathrm{B} \\
\mathrm{H} \\
\mathrm{P} \\
\mathrm{U} \\
\mathrm{R}\end{array}$} & Kesara & 'Darbarsaheb' & 400 & Ficus benghalensis (1), \\
\hline & Indus & 'Khapakalitala' & 300 & $\begin{array}{l}\text { Tamarindus indica }(1), \\
\text { Ficus benghalensis(1) }\end{array}$ \\
\hline & Kapastiguri & 'Dharamtala' & 200 & $\begin{array}{l}\text { Phoenix sylvestris (6), } \\
\text { Bambusa arundinacea }(72), \\
\text { Borassus habellifer }(14)\end{array}$ \\
\hline & & 'Pokhabaganrakhakalitala & 200 & $\begin{array}{l}\text { Syzygium cumini(1), } \\
\text { Aegle marmelos }(3), \\
\text { Streblus asper( } 4), \\
\text { Azadirachta indica(1) }\end{array}$ \\
\hline & Labvpur & Fulloratala' & 300 & $\begin{array}{l}\text { Tamarindus indica(20), } \\
\text { Azadirachta indica(1), }\end{array}$ \\
\hline
\end{tabular}




\begin{tabular}{|c|c|c|c|c|}
\hline & & & & $\begin{array}{l}\text { Opuntia dilleni(1), } \\
\text { Ficus benghalensis }(1), \\
\text { Borassus habellifer }(1) \\
\end{array}$ \\
\hline \multirow{10}{*}{$\begin{array}{l}\mathrm{I} \\
\mathrm{L} \\
\mathrm{L} \\
\mathrm{A} \\
\mathrm{M} \\
\mathrm{B} \\
\mathrm{A} \\
\mathrm{Z} \\
\mathrm{A} \\
\mathrm{R}\end{array}$} & Kharboni & 'Shivchanditala' & 400 & $\begin{array}{l}\text { Ficus benghalensis (1),Ficus } \\
\text { infectoria(1),Phoenix sylvestris (1) }\end{array}$ \\
\hline & $\begin{array}{l}\text { Kharboni } \\
\text { g.s.coloni }\end{array}$ & $\begin{array}{l}\text { 'Sitola-brahmachari- } \\
\text { Manasatala' }\end{array}$ & 150 & $\begin{array}{l}\text { Mangefera indica(1),Azadirachta } \\
\text { indica }(1)\end{array}$ \\
\hline & Dhallah & Bagratal'a & 250 & $\begin{array}{l}\text { Shorea robusta(12) Madhnuca } \\
\text { indica(1) }\end{array}$ \\
\hline & Dhallah & 'Barhuitala' & 100 & $\begin{array}{l}\text { Phoenix sylvestris (2), } \\
\text { Odina woodier(1) }\end{array}$ \\
\hline & Beloma & Ekmentala' & 150 & $\begin{array}{l}\text { Ficus religios(1) Streblus aspe(1) } \\
\text { Ficus infectoria(5) }\end{array}$ \\
\hline & Ruppur & Sannasitala' & 400 & Tamarindus indica $(9)$ \\
\hline & Halsidanga & 'Bramacharibababurotala & 300 & $\begin{array}{l}\text { Ficus benghalensis(1),Terminalia } \\
\text { arjuna }(1), \text { Syzygium cumini(2),Streblus } \\
\text { sper(5),Psidium guajava(1) } \\
\text { Artocarpus heterophyllus }(1)\end{array}$ \\
\hline & Cheelah & 'Bishaharitala' & 450 & $\begin{array}{l}\text { Bambusa arundinacea(450),Phoenix } \\
\text { sylvestris(1) }\end{array}$ \\
\hline & Sukhbazar & 'Maichampatbibidanga' & 120 & $\begin{array}{l}\text { Azadirachta indica(1),Streblus } \\
\text { asper( } 2)\end{array}$ \\
\hline & Dhallah & 'Dharmarajtala' & 300 & Phoenix sylvestris $(1)$ \\
\hline
\end{tabular}

Source: Field survey and according to local village dwellers statements. 
Table 2: list of faunal diversity related sacred groves in Bolpur sub-division area.

\begin{tabular}{|c|c|c|}
\hline $\begin{array}{l}\text { Name of the sporadic } \\
\text { birds, worm \& insects }\end{array}$ & Scientific Name & $\begin{array}{l}\text { Name of the sporadic } \\
\text { Animals Reptiles } \quad \text { Scientific Name }\end{array}$ \\
\hline$\underline{\text { Birds }}$ & & Animals \\
\hline$\overline{\text { House crow }}$ & ' Corvus splenders' & 'Musculus' \\
\hline Roufus woodpacker & 'Micropternu chyurus' & ' Ratufa indica centralis' \\
\hline Koel & 'Eudynanyas scolopacc' & 'Canis familiri's \\
\hline Owl & 'Althene branna' & 'Lepus nigricollis reficaudatus' \\
\hline Ring dove & 'Streptopelia decaocto' & 'Bos indicus' \\
\hline House sparrow & ' Passer domerticu's & ' Capra hircus' \\
\hline Pied crested cuckoo & 'Clamator gacobinus' & 'Prebytis entellus' \\
\hline Common pariah kite & 'Milvus migrar' & 'Macaca mulatta' \\
\hline Veseringed parakett & 'Psitacula krameri' & 'Canis aureus indicu' \\
\hline Tailor bird & 'Orthotomus sutoriu's & 'Bos bubalus' \\
\hline White breasted water her & n 'Amaurornis phoenicurus' & Mongoose 'Herpestes edwardsil nyula' \\
\hline Pigeon & 'Columura livia' & 'Canis lupus pallipes' \\
\hline Baran owl & 'Tyto alba'" & 'Pteropus mediu' \\
\hline Bengal vulture & 'Gyps Bengal' & 'Felis domesticus' \\
\hline Indian myna & 'Acridotheres' & \\
\hline Sarus crane & 'Grus antigone' & \\
\hline Fowl & 'Gallus domesticus' & \\
\hline \multicolumn{3}{|l|}{ Worm and insects } \\
\hline \multirow{2}{*}{\multicolumn{2}{|c|}{$\begin{array}{l}\text { White ant, WaspMosquito(Culexfatigans) } \\
\text { Cricket,Chameleon (Calotesvessircolor),Scorpion,Fire } \\
\text { fly,Fly (Musca domestica), FlyHornet, Lee Grass } \\
\text { hoper(Periplanetaanericane), Butterfly(Papileo } \\
\text { Krishna), Scorpion(Buthans tamulas), } \\
\text { Cockroach(Periplaneta anericane),Black bee. }\end{array}$}} & Reptiles \\
\hline & & $\begin{array}{l}\text { Toad Centripede(Achatina fulica), Snail, } \\
\text { Lizard ,Earthworm, Tadpole(Rana tirgina), } \\
\text { Lguana, Water snake(Naza naza). }\end{array}$ \\
\hline
\end{tabular}

Source: Field survey and according to local village dwellers statements 
Table 3: List of medicinal trees conserved with sacred groves.

\begin{tabular}{llcl}
\hline \multicolumn{2}{l}{ Name of medicinal trees } & & Applications in ayurvedic \& medicine \\
Local name & scientific name & useable parts & \\
\hline Bel & 'Aeglemarmelos' & Fruits & Dyspepsia, constipayion \\
Arjun & 'terminalia arjuna' & Stem,Bulk & Heardiseases, urinary tract infection \\
Khejur & 'Phoenix sylvestris' & Fruits & Energitc,nutrients medicine \\
Assahat & 'Ficus ligiosare' & stem, leaf & Problems regarding cemen, burn wound \\
Neem & & stem, leaf & Tyfoaid, sugar,aloepecia,sofilic \\
Mango & 'Mangifera indica' & Fruits, leaf & Burning feet syndrome,ulcer \\
Guava & 'Psidium guajava' & Fruits, leaf & Tooth sehe \\
Honey & & & Cough \\
Hatichokkhu & & leaf & Eye irritation \\
Harjora & & stem & Reduction and immobalisation. \\
\hline
\end{tabular}

